\title{
Globalisation of Education in South African Tertiary Institutions: The Case of the University of Fort Hare, South Africa
}

\author{
F.H. Nekhwevha (PhD) \\ University of Fort Hare (South Africa) \\ E-Mail: fnekhwevha@ufh.ac.za \\ T. Mambiravana \\ University of Fort Hare (South Africa) \\ A.T.Muruviwa \\ University of Fort Hare (South Africa)
}

Doi:10.5901/mjss.2014.v5n10p438

\begin{abstract}
South African tertiary education institutions are subject to global trends. This is due to the fact that despite the accountability they owe to the governments of their countries, the academic profession has increasingly become internationalized. These institutions are more than ever impacted upon by global research networks and new communication technologies. Western policies and ideologies have linked the academic institutions and systems globally. In addition, the use of English as a medium of instruction for scientific communication and teaching, in particular when combined with the internet makes communication easier and more rapid. It is in this regard that the current project aimed at assessing the role played by three variables in the globalization of education. These variables are the pedagogical process, the linguistic issue and the curriculum content. The study utilized a deductive research methodology, quantitative in nature, to investigate the globalization of education phenomenon in South African tertiary institutions as manifested in the curriculum, the teaching and learning process and the language issue. The results of the study have indicated that there is Western domination in the curriculum and reading materials, in the extensive use of the English language in all educational practices and in the free market ideology driven curriculum.
\end{abstract}

Keywords Globalization, Education, language, Global Structured Educational Agenda, Neo-liberalism

\section{Introduction}

Globalization is a set of economic and political structures and processes derived from the changing character of the goods and assets that comprise the base of the international political economy, in particular, the increasing structural differentiation of those goods and assets (Reich, 1998:5). Global education is funded by international multi-lateral institutions such as the World Bank and the Organization for Economic and Cooperation Development (Salmi et al, 2009). These institutions normally fund those tertiary education centers that adhere to a neo-liberal agenda in education. The World Bank, for instance, produces policy reports, provides financial support (for example, loans and other funding initiatives), collects and analyzes data, offers policy advice, sponsors international/regional conferences and offers technical assistance (Salmi et al, 2009). As a result of the infiltration of global processes and international organizations, the local educational set up has been influenced by Western styles of teaching and the English language. The newly introduced globalized education is characterized by the use of technology, the utilization of the English language as a medium of instruction, distant learning and community engagement programs as well as self-study as part of the learning process. The Republic of South Africa's tertiary institutions are in many ways trying to adopt and cope with these new forms of education brought by globalization. The government is also playing a vital role towards the implementation of these changes in the educational system.

The core argument of this study is that Western ideologies and policies are exerting pressure on higher education in addition to posing major threats to the traditional ethics of the local universities as well as the institutional control of education. As a result global education is biased towards the West. The major contributing factor to Western biasness is the role played by the institutions that fund global education. These multilateral institutions formulate and improvise policies that put pressure on national higher education policymakers to change the way tertiary education does its business. For this reason, higher education institutions have adopted market-like behaviors and quasi-marketization 
strategies to secure additional funding in the face of fierce competition (Nixon, 2004; Ntshoe and De Villiers, 2008: 288). Globalization affects nation states and their education systems through various mechanisms notably harmonization, dissemination, standardization, installing interdependence and imposition (Dale, 1999). Hence this study's objective was to understand how globalization has influenced teaching and learning processes at the University of Fort Hare focusing specifically on the Faculty of Social Sciences and Humanities.

\section{The Research Problem}

Homogenization of education has facilitated the teaching and learning processes in different ways, for example, the emergence of new technology in education such as the use of computers, e-mails, internet and distance learning. This encourages and facilitates self-study among the students. In addition, education was traditionally seen as a public good and as something that provided a valuable contribution to society (Altbach 2001: 2-5). However, capitalists are now increasingly seeing education as a commercial product and as a result they aim to make profit from it. On the other hand, the use of the English language as a medium of instruction has sidelined local languages and hence it is seen as promoting Western hegemony (Moyo, 2002:149-150). Therefore the position adopted by this study is that, although globalization as a process brings about positive changes, it also has negative impacts since it has allowed Western discourses to shape the current educational systems in the South.

\section{The Research Questions}

The research questions of the study are as follows:

1. Are Western perspectives and the free market ideology hegemonic in the curriculum content and the learning and teaching processes at the University of Fort Hare's Faculty of Social Science and Humanities?

2. To what extent does the use of English as a medium of instruction advances the globalization of education at the University of Fort Hare's Faculty of Social Science and Humanities?

3. Is the curriculum content of Social Science and Humanities subjects at the University of Fort Hare aligned to or reflects on the immediate life experiences of the learners and/or the African context?

\section{Research AIM}

The major aim of this study is to investigate the globalisation of education within South African tertiary institutions with a specific focus on the curriculum content, the pedagogical processes and the linguistic issues in the Faculty of Social Science and Humanities at the University of Fort Hare. The study also sought to address the following sub-objectives.

1. To ascertain whether Western perspectives and the free market ideology are hegemonic in the curriculum content and the learning and teaching process at the University of Fort Hare's Faculty of Social Science and Humanities.

2. To determine the extent to which the use of English as a medium of instruction advances the globalization of education at the University of Fort Hare's Faculty of Social Sciences and Humanities.

3. To find out if the curriculum content of Social Science and Humanities subjects at the University of Fort Hare is aligned to or reflects on the immediate life experiences of the learners and/or the African context

\section{Hypothesis}

The hypothesis of this study is that globalisation has negatively influenced the curriculum content and the teaching and learning process in the South. To test this hypothesis this study utilised a quantitative methodological approach.

\section{Research Methods}

To reiterate, the method of data collection used in this study was quantitative. Hence a survey was administered and 65 questionnaires were distributed during the 2010 calendar year to students from the Faculty of Social Science and Humanities of the University of Fort Hare who formed the major component of the research population. In addition, 20 questionnaires were also distributed to the lecturers of the same faculty who had a deeper understanding of how the teaching and learning processes were influenced by Western paradigms. The Statistical Package for the Social Sciences (SPSS) software was used for data analysis. The resultant quantitative data and research findings were presented in the form of tables, figures and percentages. 


\section{Discussion of Findings}

This section discusses the major findings of the study. The key issues investigated were the curriculum content, the pedagogical process and the linguistic issue. The three issues were selected owing to the fact that they are amongst the principal factors that determine the globalization of education in South African tertiary institutions. Hence the central argument emanating from the study is that Western ideologies and policies are exerting pressure on higher education and their innovations are posing a threat to the traditional ethics of the university as well as the institutional control of education. The main theoretical framework underpinning this study was the Global Structured Educational Agenda (GSEA) which advances the argument that the education system is rapidly driven towards competitive and financial reforms (Meyer and Ramirez, 2000; Moutsios, 2009). In arriving at the conclusion and recommendations of this study, however, GSEA insights were augmented by ideas from the world system model and the world culture theory to argue that all aspects of the countries of the South including culture and the economy have been subjected to the operational dynamics of the capitalist world system and the globalization process (Kanukisya, 2010:5; Sklair, 1999). Education, and higher education in particular, is no exception. In fact, according to the world culture theorists, the model of global education which spread from Europe during the last century is part and parcel of the global culture which is being constructed and sustained through inter alia imports of money, personnel, ideas and education curricula across the entire world resulting in homogeneity in the entire globe (Chabbott and Ramirez, 2000; Meyer and Ramirez, 2000; Ramirez and Boli, 1987, Soysal and Strang, 1989; Anderson-Levitt, 2003). As this process signifies the triumph of neo-liberalism in the entire world, the World Bank, the United Nations Educational, Scientific and Cultural Organization (UNESCO) and the Organization for Economic and Cooperation Development, amongst other multilateral institutions, have become enforcers of this global system. It is within this framework that the study found out from students and staff at the University of Fort Hare that the curriculum content supports the free market system, the reading materials are saturated with the ideas and perspectives of the West and the technology based teaching enhances students' understanding as well as leading them to different proficiencies. In addition, the findings have shown that the use of the English language as a medium of instruction put African students at a disadvantage in addition to undermining the local cultures. The following section presents some of the key findings from the study.

\section{Local Language as a Medium of Instruction}

Despite the emergence of English as the dominant medium of communication as a result of globalization, most of the respondents in this study supported the idea that a local language is more suitable as a medium of instruction owing to the fact that it makes the students to be more explicit in terms of their capacity of expression. This can be summarized by the following table that shows students' responses on their preferred language of communication and learning.

Table 1: Responses on whether a local language was a suitable medium of instruction.

\begin{tabular}{|c|c|}
\hline Response & Frequency $\%$ \\
\hline Agree & $60 \%$ \\
\hline Neutral & $10 \%$ \\
\hline Disagree & $30 \%$ \\
\hline
\end{tabular}

Source: A computer printout of a table derived from the data and findings of this study.

The table above shows whether it would be beneficial to most learners if a local language can be used as a medium of instruction. $60 \%$ of the respondents agree with the idea, $10 \%$ were neutral and $30 \%$ disagreed with the idea. According to Abdulaziz (2000), until and unless the indigenous languages of South Africa are used as languages of tuition at the tertiary level, the educational system will continue to be twisted in favour of the English-knowing elite. The mastery of English as the medium of instruction is considered to be a fundamental obstacle to university success for many black students (Cross and Carpentier, 2009). In this regard the study has shown that the use of English as a medium of instruction in higher education institutions in South Africa reflects biasness to the West and puts black students, especially those of an African origin, at a disadvantage.

\section{The Use of English as a Medium of Instruction Reflects a Bias Towards the West}

The English language is a second and a foreign language for the majority of South Africans. In most countries it is a second language of choice almost without exception. Nevertheless it is used in all educational context hence this reflects Western biasness. This assertion was agreed to by both the learners and the lecturers. The table below presents the results from the study on this issue. 
Table 2: Responses on whether the use of English as a medium of instruction reflects a bias towards the west

\begin{tabular}{|c|c|c|c|c|c|}
\hline \multicolumn{2}{|c|}{ Students } & Frequency & Percent & Valid Percent & Cumulative Percent \\
\hline \multirow{6}{*}{ Valid } & strongly disagree & 8 & 12.12 & 12.12 & 12.12 \\
\hline & disagree & 10 & 15.15 & 15.15 & 27.27 \\
\hline & not sure & 20 & 30.30 & 30.30 & 57.57 \\
\hline & agree & 8 & 12.12 & 12.12 & 69.69 \\
\hline & strongly agree & 20 & 30.30 & 30.30 & 100.0 \\
\hline & Total & 66 & 100.0 & 100.0 & \\
\hline \multirow{2}{*}{\multicolumn{2}{|c|}{ Lecturers }} & agree & & Disagree & neutral \\
\hline & & 14 & & 2 & 4 \\
\hline
\end{tabular}

Source: A computer printout of a table derived from the data and findings of this study

The table above shows that there is a strong correlation between the use of English as a medium of instruction and biasness to the West. 8 students agree, 20 strongly agree, 20 are not sure and 10 of them strongly disagree with this assertion. On the other hand, 14 lecturers agree, 4 are neutral and 10 disagree with the statement. On this issue, Kistner (2008:90-109) suggests that recently, under the influence of neo-liberal discourses, the rhetoric of both Africanization and transformation has been linked to the commercialization of the knowledge production processes mainly established and controlled by the West. Hence the depth of the impact of globalization in the South African tertiary education sector can be inferred from the domination of a foreign language in the learning and teaching processes. Despite various calls for a return to local languages as media of instruction, the English language continues to be dominant in local universities. The domination of Western practices has also shaped the curriculum content.

\section{The Curriculum Content and the Globalization of Education at the University of Fort Hare}

Due to the process of globalization, the curriculum content of subjects in the Faculty of Social Sciences and Humanities at the University of Fort Hare is being influenced by the neo-liberal discourses. Consequently, this curriculum is biased towards the West. In fact the Global Structured Education Agenda (GSEA) theory concurs that Western values have triumphed and their constituent ideologies and practices are spreading unconstrained throughout the world. In this regard, the study investigated, firstly, whether the curriculum content reflects experiences of the learner in an African context. Secondly, the study wanted to find out whether the reading program reflects global literature or not. Thirdly, the researchers wanted to ascertain whether the curriculum content guides students towards their future careers or not. Lastly the study wanted to determine if the curriculum content supports the free market ideology or not. Whilst the Western curriculum content has been integrated into the local curriculum, it must also be noted that this comes with strings attached. In fact it is arguable that Western curriculum content supports the neo-liberal ideology which advocates for the free market system.

\section{The Curriculum Content Supports the Free Market System}

The study has shown that there is a correlation between the curriculum content and the free market system. This is evidenced by the neo-liberal discourses that influence the curriculum. While education in Africa has been subsidized by the government as a social service, the Western concept of globalization advocates for the operation of the free market concept. This is because most of the Western curriculum and educational resources are acquired through the market system with technological advancement ensuring marketization. This can be witnessed by the rise in the use of electronic resources and other learning materials which institutions have to purchase online. The vast majority of online journals and other leaning materials have cemented the hegemonic principles of Western education. Without the market driving the course of education, any other form of teaching and learning is considered sub-standard. Hence the Western curriculum has been considered as the standard of all learning processes and it is only through the market that institutions of learning from the South can be able to access this education curriculum.

\section{Western Perspectives in the Reading Materials}

While the learning programs sometimes are reformed in keeping with the local context, the current basic degree structure and the curriculum remain Western-based due to the rapid use of Western textbooks and reading materials. In fact most of the textbooks used by the students in this era of global education are Western textbooks written by Western Authors. African textbooks are sidelined. The use of Western textbooks globally is part of the means by which Western perspectives and ideologies are spread. The table below provides a summary of students' views on whether the use of mainly Western textbooks in the learning and teaching processes means domination of Western ideas. 
Table 3: Student responses on whether the use of mainly Western textbooks means that Western ideas are dominant.

\begin{tabular}{|c|c|}
\hline Response & Frequency \% \\
\hline Agree & $68 \%$ \\
\hline Neutral & $14 \%$ \\
\hline Disagree & $18 \%$ \\
\hline
\end{tabular}

Source: A Computer Printout of a Table Derived From the Data and Findings of This Study

The study shows that the use of mainly Western textbooks in the learning and teaching processes means that Western ideas are dominant and hence globalized education. This is reflected by the majority of the respondents from the student respondents who agree with the statement on table 3.

\section{Conclusion and Recommendations}

The study argued that the Western ideologies and policies are exerting pressure on higher education and thus posing a threat to the traditional ethics of the university as well as the institutional control of education. The idea that the learning and teaching processes and the curriculum at the University of Fort Hare Social Science and Humanities subjects are a mirror image of globalised education from the West is in line with the views of both the world culture theory and world system model. For instance, according to the world culture theory school systems and tertiary education praxis in the rest of the world today are an outcome of the spread of global education, in form and content, in the last century from its original source in Europe. The information for this study was obtained through a quantitative research instrument, namely, a survey questionnaire. Being anchored on the GSEA theoretical framework, the study proved that linguistic, curricula and pedagogical processes determine the globalisation of education. The findings of the study support the core argument advanced herein owing to the fact that the curriculum content and the pedagogical process are saturated with Western perspectives that promote the free market system and neo-liberalism. The primary recommendation from this study is that in order to mitigate Western domination, the South African government must promote Afro-centrism in education. Afrocentrism can be promoted through the utilization of African authors and languages in education and the design of exchange programs that are supportive to African-based curricula. However this does not mean that Western perspectives will be entirely obliterated as useful and insightful aspects of Western thought and innovations will be retained.

\section{References}

Abdulaziz, A. (2000). Some issues of concern in the linguistics of African languages. In Proceedings of the Second World Congress of African Linguistics, Leipzig 1997. Köln: Rüdiger Köppe Verlag.

Altbach, P. G. (2001). Higher education and the WTO: Globalization run amok. International Higher Education, 23(1), 2-4.

Anderson-Levitt, K. (Ed.). (2003). Local meanings, global schooling: Anthropology and world culture theory. Palgrave Macmillan.

Chabbott, C., \& Ramirez, F. O. (2000). Development and education. In Handbook of the sociology of education (pp. 163-187). Springer US.

Cross, M. \& Carpentier, C. (2009). New students in South African higher education: Institutional culture, student performance and the challenge of democratisation. Perpspectives in Education, Vol 27(1), 6-18.

Dale, R. (1999b). Specifying globalization effects on national education policy: a focus on the mechanisms. Journal of Education Policy, Vol 14 (1) 1-17.

Kanikisya, B. (2010). Globalization and Inequality within the education system. A paper prepared for a PhD seminar on Sociology of Education, University of Iceland, Iceland, $14^{\text {th }}$ May 2010.

Kistner, U. (2008). Africanization in tuition: African National Education? Mediations, 24(1):90-109, Fall.

Meyer, J. W. \& Ramirez, F. O. (2000). The world institutionalization of education. Discourse formation in comparative education, 111-132.

Meyer J \& Ramirez, F. (2000). The world institutionalization of education. In J Schriewer (ed). Discourse formation in comparative education. New York: Peter Lang. (pp 111-132).

Moutsios, S. (2009). International organisations and transnational education policy. Compare, 39(4), 469-481.

Moyo, T. (2002). Mother tongues versus an ex-colonial language as media of instruction and the promotion of multilingualism. South African Journal of African Languages, Vol 22 (2), 2000-2011

Nixon, J. (2004). A profession in crisis? In D. Hayes (ed.). Key Debates in Education. London: Taylor and Francis. 165-169.

Ntshoe, I. \& De Villiers, P. (2008). Steering the South African higher education sector towards transformation. Perspectives in Education,Vol 26(4), 17-27.

Ramirez, F. O. \& Boli, J. (1987). The political construction of mass schooling: European origins and worldwide institutionalization. Sociology of education, 2-17.

Reich, S. (1998). What is Globalization. The Helen Kellogg Institute for International Studies, Working Paper \# 261

Salmi, J., Hopper, R. \& Bassett, R. (2009). Transforming higher education in developing coun-tries: The role of the World Bank. In R. Bassett \& A. Maldonado (Eds.). International organizations and higher education policy: Thinking globally, acting locally? (pp. 99-112). NewYork: Routledge.

Sklair, Leslie (1999). Social movements and global capitalism. In Roberts, J. Timmons and Hite, Amy, (eds.). From Modernization to Globalization: Perspectives on Development And social Change. Oxford: Wiley-Blackwell. pp. 328-339

Soysal, Y. N. \& Strang, D. (1989). Construction of the first mass education systems in nineteenth-century Europe. Sociology of education, 277-288. 